\title{
ETHNO-MEDICINAL PROPERTIES OF DACTYLORHIZA HATAGIREA IN HIGHER HIMALAYAN VILLAGES OF RUDRAPRAYAG DISTRICT OF UTTARAKHAND
}

\author{
K.P. Chamoli and Hariom Sharan
}

Department of Botany, Govt. P.G. College, Augustyamuni (Rudraprayag) UK-246421

Corresponding Author Email Id: kpchamoli5@gmail.com

Received: 23.10.2019; Revised: 15.11.2019; Accepted: 02.12.2019

(C)Society for Himalayan Action Research and Development

\begin{abstract}
The present communication deals with studies pertaining to field observations recorded on indigenous therapeutic applications of Dactylorhiza hatagirea (D. Don) Soo among the native people inhabiting high mountain areas of Uttarakhand, in western Himalaya. Information gathered from natives of the areas surveyed, indicated its uses to cure various diseases like dysentery, diarrhoea, chronic fever, cough, stomachache, wounds, cuts, burns, fractures, general weakness, etc., and widely used in modern medicine. Therefore, an attempt has been made to assess the medicinal potential of the species both in traditional as well as in modern medicine system. This paper provides the relevant properties of the high value medicinal orchid.
\end{abstract}

Keywords: Ethno-medicinal, Orchid, Traditional Knowledge, Rudraprayag, Uttarakhand

\section{Introduction}

Orchids are known worldwide for their fascinating and long lasting flowers. Dactylorhiza hatagirea (D. Don) Soo belongs to the family Orchidaceae. The plant is native and near endemic to Himalayan region (Badola and Aitken, 2003; Samant et al., 1998; Ved et al., 2003; Pant and Rinchen, 2012). In India, about 1,229 species belonging to 184 genera (Chowdhery, 1999) are distributed in a wide range of climatic conditions ranging from tropical-subtropical to temperatealpine deserts. Of the total species, more than $30 \%$ are endemic to India (Jain and Mehrotra, 1984). Despite the availability of a large number of species, very few orchids are known for their therapeutic significance. Dactylorhiz ahatagirea (D. Don) Soo (synonyms-Orchis hatagirea D. Don, O. latifolia auct. non-Linn.) is one of the beautiful orchids having significant medicinal value. Dactylorhiza hatagirea is a terrestrial, perennial herb, $20-50 \mathrm{~cm}$ tall with fleshy, flattened, palmately lobed or finger like tuberous roots, leaves linear-lanceolate to ellipticlinear, upto $15 \mathrm{~cm}$ long, terminal, dense, cylindrical spike, seeds minute, black or dark-brown in colour (Fig.1). D. hatagirea is distributed throughout Himalayan region from East to West between the elevations of 2,800-4,500 m above mean sea level. In Western Himalaya, it has been reported from various locations of Jammu \& Kashmir (Dhar and Kachroo, 1983) Himanchal Pradesh (Aswal and Mehrotra, 1994), and Uttarakhand (Hajra and Balodi, 1995). It is, perhaps the only orchid recorded from the highest altitude in western Himalaya (Rau, 1975). The tubers of this species, commonly sold as 'Salampanja' are known to yield a high quality 'Salep' which is extensively used in local medicines as nervine tonic for its astringent and aphrodiasic properties (Viz et al., 1992). D. hatagirea is known by its different vernacular names such as Salam-panja, Hatajiri, Hatajori, Salep or Marsh orchid. It is evident that Salam-Panja is extensively used in Indian systems 
of medicine particularly in Ayurveda, Siddha and Unani Medicine as an aphrodisiac and nervine tonic (CSIR, 1966; Singh, 1999). However, no information on the traditional medicinal uses of salam-panja pertaining to any specific area or tribe, were brought out of far. This is why that the present study is aimed to document and bring out the comprehensive account on the prevailing indigenous knowledge related to medicinal uses of $D$. hatagirea among the people of Rudraprayag district in Uttarakhand.

\section{Materials and Methods}

The study area lies in Ukhimath block, the Northwest part of Uttarakhand. The area falls between $30^{\circ} 30^{\prime}-30^{\circ} 45^{\prime} \mathrm{N}$ Latitude and $79^{\circ} 0$ $79^{0} 15^{\prime} \mathrm{E}$ Longitude and covers an area of about $400 \mathrm{sq} \mathrm{km}$. The altitude ranges between 1,000 to 6,000 asl. Field surveys were undertaken in almost all parts of the Ukhimath block during 2015-2018 including frequent field explorations regarding floristic survey and ecological studies in the Triyuginarayn and Tungnath areas. Efforts were made to record the prevailing indigenous knowledge related to medicinal applications of Salam-panja among the native people. During 2015-2018, several tours were conducted in the different localities of the above areas during monsoon period only. Close contacts were developed with local people particularly traditional healers called Vaidyas in different villages of Ukhimath block of Rudraprayag district. The survey includes information about local names of medicinal plants, plant parts used in treatment and number of ailments being treated by medicinal formulations by local inhabitants. The detailed information on medicinal uses and mode of prescription were also recorded. In addition, voucher specimens of plants were collected processed, documented, and finally deposited in theherbarium of the Department of Botany, Govt. P.G. College, Augustyamuni as reference material. Observations on the current status of distribution of $D$. hatagirea in nature were also recorded.

\section{Results and Discussion}

The study highlights that in absence of modern healthcare facility, people in the study area are dependent on plants for medicinal purposes. During the field studies, it was observed that a number of plants, growing in nature, are used for medicinal purposes by the native people. D.hatagirea, locally known as Hatajori, Panja, Salam panja, Salam pamisri has been identified as one of the potential species used as a healing herb for treating aliments like stomachache, general debility, bone-fracture and other diseases (Gupta et al., 1998). However, many Ayurvedic herbs are prescribed alone to cure different ailments but the Dactylorhiza hatagirea is highly significant in terms of its uses in this area (Semwal et al., 2009). The plant is used alone or as a mixture along with other ingredients (Brij Lal et al., 2004). In the interior parts of this block, people still depend on the plants for medicinal purpose and are very much concerned about their exploitation in the wild (Negi et al. 1993; Semwal et al., 2009). The information in detail is given in Table 1.

\section{Conservation status}

$D$. hatagirea has been categorized as critically endangered species (CAMP status), critically rare (IUCN status) and is listed under Appendix II of CITES (Kala, 2000; Samant et al., 2001), with the current restricted regional distribution in only a few pockets of Jammu \& Kashmir, Himachal Pradesh and Uttarakhand (Ved and Tandon, 1998). Efforts for its conservation are going on at HAPPRC, Srinagar under NMHS program of Ministry of Environment, Forests and Wildlife, Government of India.

\section{Conclusion}

The present study reveals that $D$. hatagirea is a valuable medicinal plant, but to harness the potential of this plant, documentation of its indepth traditional utility and long term ecological monitoring are urgently required. Therefore, call for its conservations strategies combining traditional wisdom and modern scientific tools and 
techniques ensuring its protection, mass propagation, and sustainable utilization becomes imperative.

Table 1. Medicinal uses of $D$. hatagirea.

\begin{tabular}{|l|l|l|}
\hline \multicolumn{1}{|c|}{ Ailments } & \multicolumn{1}{|c|}{ Mode of prescription } & \multicolumn{1}{c|}{ Distribution in the area } \\
\hline $\begin{array}{l}\text { General } \\
\text { weakness }\end{array}$ & $\begin{array}{l}\text { Roots along with the fruit pulp of kunja } \\
\text { (wild rose), Shilajeet and other ingredients } \\
\text { are crushed and made into paste. The pills } \\
\text { made from the paste are given as tonic in } \\
\text { case of general weakness and debility. }\end{array}$ & $\begin{array}{l}\text { Triyuginarayan, Mansoona, Kalimath, } \\
\text { Gaurikund, } \\
\text { Chopta }\end{array}$ \\
\hline Cough & $\begin{array}{l}\text { The fresh tubers extract is taken to treat } \\
\text { cough. }\end{array}$ & $\begin{array}{l}\text { Toshi, Triyuginarayan, Sonprayag, } \\
\text { Makkumath, SirsiBdasu }\end{array}$ \\
\hline Bone fracture & $\begin{array}{l}\text { The boiled extract of tubers mixed with } \\
\text { milk is given orally in the treatment of } \\
\text { bone fracture. }\end{array}$ & $\begin{array}{l}\text { Triyuginarayn, Sirsi, Rampur, Sitapur, } \\
\text { Kimana }\end{array}$ \\
\hline Spermatorrhoea & $\begin{array}{l}\text { The processed (refined) tubers mixed with } \\
\text { misri (sugar crystal) are mixed with milk } \\
\text { and given to control spermatorrhoea. }\end{array}$ & $\begin{array}{l}\text { Toshi, Sirsi, Badasu, Makkumath, } \\
\text { Kotma }\end{array}$ \\
\hline Stomachache & $\begin{array}{l}\text { The fresh root juice is given in cough and } \\
\text { stomachache. }\end{array}$ & $\begin{array}{l}\text { Triyuginarayan,Baniyakund,Gaurikund, } \\
\text { Chopta, Tungnath }\end{array}$ \\
\hline Wound healing & $\begin{array}{l}\text { The paste obtained after rubbing tubers on } \\
\text { stones, is applied on boils for wound } \\
\text { healing caused due to burnt. }\end{array}$ & $\begin{array}{l}\text { Triyuginarayn, } \\
\text { Rampur,Sitapur, } \\
\text { Makkumath,Kalimath }\end{array}$ \\
\hline Diarrhoea & $\begin{array}{l}\text { Tuber paste is taken orally to cure diarrhea } \\
\text { Tiryuginarayan, Sirsi, Rampur, Sitapur, } \\
\text { Kimana, Makumath, Sari,Ransi }\end{array}$ \\
\hline
\end{tabular}

\section{References}

Aswal, B.S. and B.N. Mehrotra(1994). Flora of Lahaul-Spiti. Bishen Singh Mahendra Pal Singh, Dehra Dun, India.

Badola, H. K.and S. Aitken (2003). The Himalayas of India: A treasury of Medicinal plant under siege. Biodiversity, 4: 3-13.

Brij Lal, H.R. Negi, R.D. Singh, and P.S. Ahuja (2004). Medicinal uses of Dactylorhiza hatagirea among the natives of higher altitudes in western Himalaya. J. Orchid Soc. India, 18(1-2): 97-100

Chowdhery, H.J. (1999). Floristic diversity in Himachal Pradesh. In: Floristic Diversity and Conservations Strategies in India, (eds. V. Mudgal and P.K. Hajra) Vol. 11, Botanical Survey of India, Dehra Dun, India.
CSIR. (1966). The Wealth of India (raw materials), Vol. 7. PID (Council of Scientific and Industrial Research), New Delhi, India.

Dhar, U. and P. Kachroo (1983). Alpine Flora of Kashmir Himalaya. Scientific Publishers, Jodhpur, India.

Gupta, A. K., S.K. Vats, and Brij Lal (1988). How cheap a medicinal plant can be? Curr. Sci., 14(7): 565-66.

Hajra, P.K. and B. Balodi (1955). Plant wealth of Nanda Devi Biosphere Reserve. Botanical Survey of India, Calcutta, India.

Jain, S.K. and A. Mehrotra (1984). A Preliminary Inventory of orchids in India. Botanical Survey of India, Howrah, India.

Kala, C. P. (2000). Status and conservation of rare and endangered medicinal plants in the Indian Trans-Himalayas. Biol. Cons., 93(3): 371-79. 
Negi, K.S., J.K. Tiwari, R.D. Gaur, and M.C. Pant (1993). Notes on ethnobotany of five districts of Garhwal Himalaya, Uttar Pradesh, India. Ethnobotany, 5(1 \& 2), 73-81.

Pant, S. and T. Rinchen (2012). Dactylorhiza hatagirea: A High value medicinal orchid. Journal of Medicinal Plants Research Vol. 6 (19), pp 3522-3524.

Rau, M.A. (1975).High Altitude flowering Plants of West Himalaya. BSI, Howrah, India.

Samant, S. S., U. Dhar, and L.M.S. Palni (1998). Medicinal Plants of Indian Himalayan: Diversity, Distribution Potential Values. HIMAVIKAS Publication. No. 13, Gyanodaya Prakashan, Nainital, India.

Samant, S.S., U. Dhar, R. S. Rawal (2001). Himalayan Medicinal Plants Potential and Prospects. Gyanodaya Prakashan, Nanital.

Singh, P.B. (1999). IIIustrated Field Guide to Commercially Important Medicinal and Aromatic Plants of Himachal Pradesh. Society for Herbal Medicine and Himalayan Biodiversity, Mandi, India.

Semwal D. P., P. PardhaSaradhi, C. P. Kala and B. S. Sajwan (2009). Medicinal plants used by local Vaidyas in Ukhimath block, Uttarakhand.Indian Journal of Traditional Knowledge, Vol. 9(3), pp 480-485.

Ved, D. K. and V. Tandon (1998). CAMP Report for High Altitude Medicinal Plants of JammuKashmir and Himachal Pradesh (eds. D. K. Ved and V. Tandon) FRLHT, Bangalore, India.

Viz, S. P., R. C. Srivastav, A. K. Mainra(1922). On the occurrence of Dactylorhiza hatagirea (D. Don) Soo in Sikkim. Orchid News, 8-9: 14-15.

$* * * * * * * * *$ 